\section{Who Should They Relate To? A Study For the Identification and Analysis of Criteria to the Partners' Selection in Inter-Organizational Networks}

\author{
Denise Rossato Quatrin ${ }^{\dagger}$ \\ Universidade Federal de Santa Maria \\ Breno Augusto Diniz Pereira ${ }^{\Omega}$ \\ Universidade Federal de Santa Maria
}

\begin{abstract}
The selection of partners is strategic in inter-organizational networks. One of the most important aspects is the definition of criteria for selection, that are the minimal characteristics required from those prospected. This study aimed to identify the most important criteria for the selection of members in horizontal inter-organizational networks, also describing their influence on network activities. First, we applied 120 questionnaires to managers of inter-organizational networks to identify the degree of importance of criteria previously treated in the literature. After, we interviewed 16 managers enabling us to identify other criteria, as well as understanding their influence on network activities. All of the 20 criteria from the literature were considered with significant importance by managers and the following criteria were added: trustworthiness, entrepreneur's profile and company lifetime. The results aim to contribute to the selection of partners and provide information for the construction of the inter-organizational networks literature.
\end{abstract}

Keywords: Inter-organizational networks, Partner's selection, Criteria, Quantitative and qualitative research.

\section{INTRODUCTION}

Inter-organizational networks are composed mainly, from the perception that the joining of forces between companies makes each company stronger before complex problems. Child and Faulkner (1998) claim that the cooperation between companies are generally established when two or more organizations collaborate with each other, facing a threat to the development, that is common to both, or even, before an opportunity that would not be achieved if the organizations acted individually. More recently, Gulati (2007) defined them as lasting agreements between two or more businesses involving exchange, sharing or co-development of products, technologies and services.

Despite the increasing use of inter-organizational networks, in organizational practice and in the literature there are still differences regarding the use of the term, as shown in the following excerpt:

Although inter-organizational networks are by now a commonly understood phenomenon of organizational life, it is not always clear exactly what organizational scholars are talking about when they use the term. Even the term network is not always used. Many who study business, community, and other organizational networks prefer to talk
Corresponding author:

† Universidade Federal de Santa Maria.

E-mail: dequatrin@gmail.com

$\Omega$ Universidade Federal de Santa Maria

E-mail: brenodpereira@gmal.com

Received: $11 / 20 / 2015$.

Revised: $12 / 09 / 2015$

Accepted: 02/16/2016

Published Online: 02/06/2017.

DOI: http://dx.doi.org/10.15728/bbr.2017.14.3.4 
about partnerships, strategic alliances, inter-organizational relationships, coalitions, cooperative arrangements, or collaborative agreements. (PROVAN, FISH e SYDOW, 2007, p. 480).

The same authors introduced the term "whole network", which they characterize as "a group of three or more connected organizations in order to facilitate the achievement of a common goal. That is, networks ".... are often formally created and governed and objectiveoriented, instead of occurring by chance" (PROVAN, FISH, SYDOW, 2007, p. 482).

Considering that inter-organizational networks may have different configurations, we note that the study objective present article are the inter-organizational networks characterized as follows: a) formally constituted legal organizations; b) have a certain period of existence; c) they seek to achieve the objectives of the partners as well as aiming to achieve their own goals; d) the power of decision is made in a participatory manner; e) they have an organizational structure regardless of the partner companies (QUATRIN, 2015).

Given the specifications, inter-organizational networks are formed by partner organizations, which must present a particular interdependence, aimed at the success of joint actions. Thus, in the selection of members to compose an inter-organizational network, it is imperative to trace and analyze the profile of prospected organizations, considering specific criteria. Beamish and Banks (1987) corroborate this statement by stating that the selection of partners influences the performance of inter-organizational networks.

Based on this context, we have the following research problem: which criteria must be observed when selecting partners in a horizontal inter-organizational network, aiming for a successful partnership?

To respond to the research problem, the present study aims to identify, from the literature and data collection, the important criteria for the selection of partners in horizontal interorganizational networks, also describing their influence on network activities.

As a basis for this discussion, we then approach the theory relevant to inter-organizational networks, and more specifically, to the criteria for the selection of partners already identified in the context of various types of inter-organizational relationships. After, we report the method used in this study and, from there, we present and discuss the results. The last chapter of the article includes the final considerations, with an analysis of the results, assessment of contributions and limitations of the study, as well as suggestions for future studies.

\section{INTER-ORGANIZATIONAL NETWORKS: CONTEXTUALIZATION}

Inter-organizational networks are widely used strategies in order to join forces, because, according to Atouba and Shumate (2010), Lee and Monge (2011) and Müller-Seitz (2012), they are able to provide the generation of results that transcend the sum of individually earned organizational resources.

Facing the different types that can present inter-organizational networks, Gulati and Gargiulo (1999) distinguish horizontal networks and vertical networks, and this research is limited to the study of horizontal inter-organizational networks, which include companies in the same sector, and which remain legally independent and cooperate on predefined aspects (WEGNER and PADULA, 2010).

There are countless initial objectives established in the formation of inter-organizational relationships. The possibility to obtain increased bargaining power, access to new markets and scarce resources in inter-organizational relationships was dealt with by Pfeffer and Salancik (1978). Williamson (1985) addressed the motivation from the individual search for reduction of transaction costs, and Jarillo (1988) considers the motivation to compete strategically. Also, Keil (2000) cites five motivating factors for the formation of interorganizational relationships: required formation, cost minimization, access to resources, learning, strategic positioning. 
BBR

It is noteworthy that many inter-organizational networks are formed where the initial intention of partners is to obtain financial benefits. Lima (2007) noted that in different cooperation networks of Rio Grande do Sul, the entry of partners into networks was motivated primarily by the search for cost reduction, increased bargaining power and better prices and discounts, factors already diagnosed in previous studies and again highlighted in recent studies, related to a financial return (INGRAM and BAUM, 1997; KEISTER, 1998; GAZLEY, 2008; KUNZLER and BULGACOV, 2011).

Depending on the objectives for which there is the formation of a network, the criteria that will be analyzed in prospected companies different. In the context of inter-organizational relationships, the pursuit and achievement of planned objectives depend on the profile of partner companies, which refers to the importance of analyzing the partners selection criteria, discussed below.

\section{CRITERIA FOR THE SELECTION OF PARTNERS}

The profile of partners of an inter-organizational network is directly related to its operational area, and the results obtained in the activities performed together. In this sense, the selection of partners from the previously defined criteria analysis becomes essential for the sustainability of an inter-organizational network. Selecting good partners for inter-organizational networks leverages the business and improves the performance of all members of the network (EISENHARDT and MARTIN, 2000; IRELAND, HITT and VAIDYANATH, 2002).

The selection process, which involves the definition of criteria to be analyzed in the prospected companies, has been dealt with as being strategic in the functioning of interorganizational relationships. Dacin, Hitt and Levitas (1997) claim that, although the search for suitable partners requires caution and time, the choice of partners is an important factor, that affects the performance of a relationship.

Evidencing the influence of the criteria for partner selection, Varis and Salminen (2000) conducted a study in order to build a preliminary framework for the selection of partners in the information and communication technology sector. The framework was built from previous studies and from conducting interviews. The results of the study are set forth in Figure 1.

In figure 1 the influence of partner selection criteria for forming a partnership is evident, which is directly related to the results obtained with their activities. In this case, the authors found that environmental factors such as convergence, motivate partnerships. The partnership training process includes various stages, of which the selection is one of the most important. And finally, the process of formation of partnership interferes with the results obtained with the partnership.

Regarding the relationship between the selection criteria used and the sustainability of a relationship, Galbraith (1998), Dekker (2004), Dyer and Chu (2003) and Klein and Pereira (2014) assert that criteria are used to assess the congruence between the prospected and other members of the network and, if they are not observed, there is the possibility of the new partner not staying in the relationship. Complementarily, Bierly III and Gallagher (2007) assert that the identification of criteria for partner selection is a precondition for the success of an inter-organizational relationship.

In knowing, then, of the importance of defining criteria for the selection of partners, in view of the search for the success of a partnership, below we compiled the criteria mentioned in the literature of various types of inter-organizational relationships (Table 1).

With the main criteria for the selection of partners in inter-organizational relationships exposed, we present the method used for data collection and analysis. 


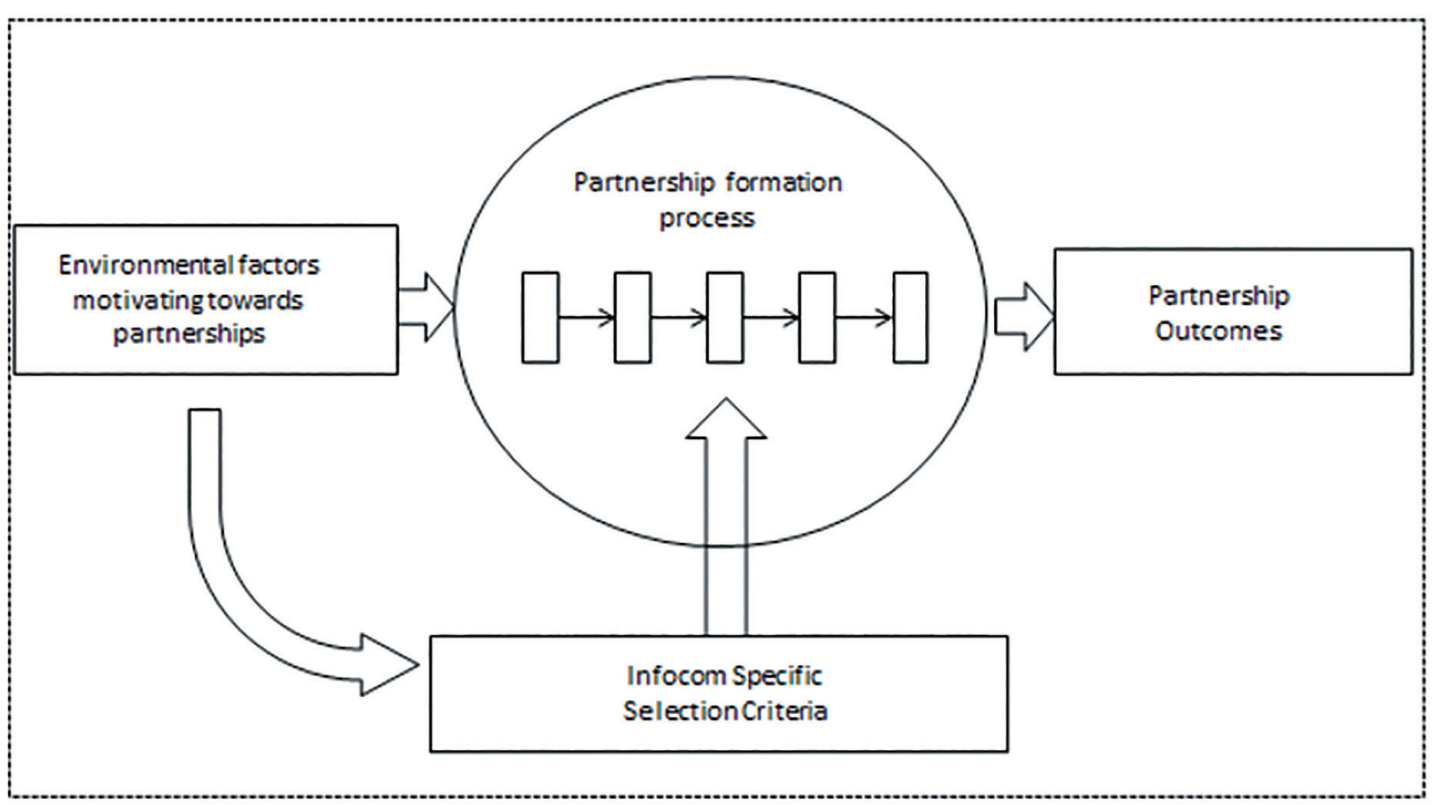

Source: Varis and Salminen (2000, p. 5)

Figure 1. Framework for building partnerships and partner selection

\section{METHOD}

This study aims to identify, based on theoretical evidence and primary data collection, the most important criteria for selecting partners in horizontal inter-organizational networks, and the influence on the network's activities.

First of all, we searched the criteria for partner selection stressed in the literature of different types of inter-organizational relationships, already exposed in the theoretical framework. They were the starting point for the construction of the questionnaire, which consisted of two parts (Table 2): I demographic profile and II Criteria for partner selection. Part II was subdivided in in three: strategic, related to the prospected and related to the resources.

For each criterion, the sample indicated the degree of importance, considering a fivepoint Likert scale: not important (1), of little importance (2), indifferent (3), important (4) and very important (5). The questionnaire was applied to 120 managers of interorganizational networks, who hold positions as president or are responsible for the process of partners expansion. Of the total, 62 questionnaires were administered in person and 58 were completed online. The analysis of the questionnaires was performed from the calculation of averages and the Cronbach's alpha for the three criteria subgroups.

Moreover, interviews were conducted in person with 16 managers who were randomly termed as E1, E2, E3, E4, E5, E6, E7, E8, E9, E10, E11, E12, E13, E14, E15 and E16 to maintain the anonymity of responses. The managers interviewed occupy hold positions as president or are responsible for the expansion process of partners; in this position they may be partners or hired to take over the function. From a semi-structured interview, respondents were asked about the criteria they consider as important in partner selection, the relative justification. In addition, respondents were able to make general comments about how managers perceive the relevance of the analysis of the criteria among the prospected. We conducted an interpretative analysis of the interviews, which according to Ricoueur (2000), assumes the inclusion of the researcher in the interpretation of data.

The results obtained with the specified method are exposed below. 
Table 1. Criteria for partner selection

\begin{tabular}{ll}
\hline Criterion & Central idea \\
\hline Strategic compa- & $\begin{array}{l}\text { The partner's strategies } \\
\text { tibility }\end{array}$ \\
& $\begin{array}{l}\text { Network's; it presents the } \\
\text { same policies and tactics, } \\
\text { ensuring alignment of ob- } \\
\text { jectives }\end{array}$
\end{tabular}

Authors

Williams and Lilley (1993); Dacin, Hitt and Levitas (1997); Hagedoorn and Duysters (2002); Das and Teng (2002); Wahyuni (2003); Chen, Lee and Wu (2008); Duisters, Duysters and De Man (2011)

\begin{tabular}{ll}
\hline $\begin{array}{l}\text { Strategic im- } \\
\text { portance of the } \\
\text { network for the } \\
\text { partner }\end{array}$ & $\begin{array}{l}\text { How important is the Ne- } \\
\text { twork for the partner }\end{array}$ \\
\hline $\begin{array}{l}\text { Added value for } \\
\text { the customer }\end{array}$ & $\begin{array}{l}\text { Joint activities add value to } \\
\text { customers }\end{array}$ \\
\hline Complementarity & $\begin{array}{l}\text { The partners are mutually } \\
\text { dependent to achieve their } \\
\text { goals }\end{array}$
\end{tabular}

Spekman, Isabella and Macavoy (2000); Wahyuni (2003); Hagedoorn and Duysters (2002); Das and Teng (2002); Dacin, Hitt and Levitas (2007); Dekker (2004); Poppo and Zenger (2002); Duister, Duysters and De Man (2011) Das and Teng (1998); Walters, Peters and Dess(1994); Doz (1996); De Man, Duysters and Vasudevan (2001); Wahyuni (2003); Duisters, Duysters and De Man (2011) Williams and Lilley (1993); Kanter (1994); Dacin, Hitt and Levitas (1997); Spekman, Isabella and Macavoy (2000); Hagedoorn and Duysters (2002); Das and Teng (2002); Doumaet al. (2000); Poppo and Zenger (2002); Wahyuni (2003); Varis, Kuivalainen and Saarenketo (2005); Vlaar et al. (2006); Duisters, Duysters and De Man (2011)

\begin{tabular}{|c|c|c|}
\hline $\begin{array}{l}\text { Partner's insight } \\
\text { for innovation }\end{array}$ & $\begin{array}{l}\text { Willingness to innovate, take } \\
\text { risks, being creative }\end{array}$ & $\begin{array}{l}\text { Das and Teng (1998); Varis and Conn (2002); Holtbrugge } \\
\text { (2004); Dacin, Hitt and Levitas (2007); Duisters, Duysters } \\
\text { and De Man (2011) }\end{array}$ \\
\hline $\begin{array}{l}\text { Willingness to } \\
\text { share resources }\end{array}$ & $\begin{array}{l}\text { Resources include employe- } \\
\text { es, knowledge, products, } \\
\text { production capacity }\end{array}$ & $\begin{array}{l}\text { Geringer (1991); Dacin, Hitt and Levitas (1997); Chung, } \\
\text { Singh and Lee (2000); Duisters, Duysters and De Man } \\
\text { (2011) }\end{array}$ \\
\hline Location & $\begin{array}{l}\text { Favorable location for ne- } \\
\text { gotiations between partners } \\
\text { and between company and } \\
\text { customers }\end{array}$ & Geringer (1991); Marxt and Link (2002) \\
\hline $\begin{array}{l}\text { Previous experien- } \\
\text { ce with coopera- } \\
\text { tion }\end{array}$ & $\begin{array}{l}\text { Knowledge related to ne- } \\
\text { tworks, level of experience } \\
\text { with network management }\end{array}$ & $\begin{array}{l}\text { Devlin and Bleakly (1988); Dacin, Hitt and Levitas } \\
\text { (1997); Chung, Singh and Lee (2000); Marxt and Link } \\
\text { (2002); Chen, Lee and Wu (2008); Duisters, Duysters and } \\
\text { De Man (2011) }\end{array}$ \\
\hline $\begin{array}{l}\text { Personal rela- } \\
\text { tionships }\end{array}$ & Coexistence with the partner & $\begin{array}{l}\text { Dacin, Hitt and Levitas (1997); Duysters et al. (1999); } \\
\text { Dacin, Oliver and Roy (2007); Duisters, Duysters and De } \\
\text { Man (2011) }\end{array}$ \\
\hline Commitment & $\begin{array}{l}\text { Committed to the success of } \\
\text { the partnership }\end{array}$ & $\begin{array}{l}\text { Geringer (1991); Williams and Lilley (1993); Brouthers, } \\
\text { Brouthers and Wilkinson (1995); Spekman, Isabella and } \\
\text { Macavoy (2000); Douman (2000); De Man, Duysters and } \\
\text { Vasudevan (2001); Marxt and Link (2002); Poppo and } \\
\text { Zenger (2002); Nielsen (2003); Varis, Kuivalainen and } \\
\text { Saarenketo (2005); Duisters, Duysters and De Man (2011) }\end{array}$ \\
\hline $\begin{array}{l}\text { Compatibility of } \\
\text { objectives }\end{array}$ & $\begin{array}{l}\text { Objectives that can be pur- } \\
\text { sued simultaneously and are } \\
\text { complementary }\end{array}$ & $\begin{array}{l}\text { Bronder and Pritzl (1992); Brouthers, Brouthers and Wi- } \\
\text { lkinson (1995) }\end{array}$ \\
\hline $\begin{array}{l}\text { Motivation to } \\
\text { cooperate }\end{array}$ & Willingness to cooperate & $\begin{array}{l}\text { Geringer (1991); Brouthers, Brouthers and Wilkinson } \\
\text { (1995); Spekman, Isabella and Macavoy (2000);Douman } \\
\text { (2000); De Man, Duysters and Vasudevan (2001); Nielsen } \\
\text { (2003); Duisters, Duysters and De Man (2011) }\end{array}$ \\
\hline
\end{tabular}




\begin{tabular}{ll}
\hline $\begin{array}{l}\text { Organizational } \\
\text { culture }\end{array}$ & $\begin{array}{l}\text { Norms and values of the partner } \\
\text { organization, open or closed, etc. }\end{array}$
\end{tabular}

Dacin, Hitt and Levitas (1997); Spekman, Isabella

ni (2003); Vlaaret al. (2006); Chen, Lee and Wu

(2008); Duisters, Duysters and De Man (2011)

\begin{tabular}{lll}
\hline Partner reputation & The partner's image & $\begin{array}{l}\text { Duysters et al. (1999); Dacin, Oliver and Roy } \\
\text { (2007); Duisters, Duysters and De Man (2011) }\end{array}$ \\
\hline
\end{tabular}

Advantage for Division of transaction costs, im- Geringer (1991); Stafford (1994); Perks (2000)

reducing cost provements, purchases

Size of organiza- $\quad$ Number of employees, turnover of Kogut (1988); Williams and Lilley (1993); Brou-

tion employees, sales volume per year. thers, Brouthers and Wilkinson (1995); Tracey,

Corporations work best when the- Vanderembse and Lim (1999); Duisters, Duysters

re is little difference in size betwe- and De Man (2011)

en the companies

Bargain condition The partner's position compared Walters, Peters and Dess (1994); Doz (1996); Das to other market competitors and Teng (1998); Park and Ungson (2001); De

Man, Duysters and Vasudevan (2001); Wahyuni

(2003); Duisters, Duysters and De Man (2011)

\begin{tabular}{lll}
\hline $\begin{array}{l}\text { Cooperative cul- } \\
\text { ture }\end{array}$ & $\begin{array}{l}\text { All organizations involved have } \\
\text { to cooperate in the activities and } \\
\text { in terms of learning, sharing their } \\
\text { knowledge }\end{array}$ & $\begin{array}{l}\text { Bronder and Pritzl (1992); Stafford (1994); Brou- } \\
\text { thers, Brouthers and Wilkinson (1995); Perks } \\
(2000)\end{array}$ \\
\hline $\begin{array}{l}\text { Financial resour- } \\
\text { ces }\end{array}$ & $\begin{array}{l}\text { Return on investment, financial } \\
\text { health }\end{array}$ & $\begin{array}{l}\text { Contractor and Lorange (1988); Geringer (1991); } \\
\text { Williams and Lilley (1993); Stafford (1994); } \\
\text { Chen, Lee and Wu (2008); Duisters, Duysters } \\
\text { and De Man (2011) }\end{array}$ \\
\hline
\end{tabular}

Technological Matching technology, technologi- Das and Teng (1998); Spekman, Isabella and Ma-

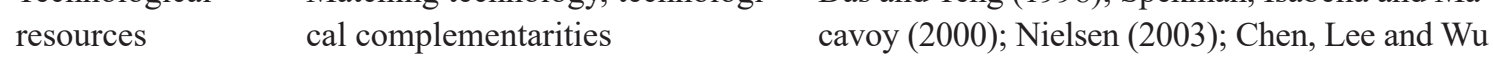

(2008); Duisters, Duysters and De Man (2011)

Fonte: elaborado pela autora.

\section{PRESENTATION AND DISCUSSION OF RESULTS}

In this chapter, we discuss first the profile of inter-organizational networks that make up the sample of the study and after, we present and describe the results relating to the criteria for the selection of partners.

\subsection{SAMPLE PROFILE}

In order to better understand the context of the study, we present a characterization of interorganizational networks sample components, which is formed by inter-organizational networks that have, on average, 10 years of experience - the oldest has 38 years' experience and the youngest 1 year experience. With regard to the time of operation of enterprises, the year 2000 is characterized by the formation of 8 sample networks, a number that surpasses all previous years. This increase in the number of networks in 2000 may be related to the Cooperation Networks Program*, not only due to some of them having been formed by the Program, but also due to the influence it had on the formation of inter-organizational networks separate from the Program. It is worth noting also the years of 2004 and 2013, when the formation of twelve inter-organizational networks took place, with that being the highest annual value.

* O Programa Redes de Cooperação foi uma iniciativa lançada em 2000 pela Secretaria do Desenvolvimento e dos Assuntos Internacionais (SEDAI) do Rio Grande do Sul. Atualmente, o Programa é desenvolvido pela Secretaria da Economia Solidária e Apoio à Micro e Pequena Empresa (SESAMPE), sendo que o objetivo é "fomentar a cooperação entre empresas, gerar um ambiente estimulador ao empreendedor e fornecer suporte técnico necessário à formação, consolidação e desenvolvimento das Redes". 
Table 2. Questions comprising the questionnaire

\begin{tabular}{llll}
\hline Construct & Definition & $\begin{array}{l}\text { Varia- } \\
\text { bles }\end{array}$ & Explanation \\
\hline \multirow{2}{*}{$\begin{array}{l}\text { I Demogra- } \\
\text { phic profile }\end{array}$} & $\begin{array}{l}\text { Characteristics that } \\
\text { define and distin- } \\
\text { guish each resear- } \\
\text { ched inter-organiza- } \\
\text { tional network. }\end{array}$ & 1 & $\begin{array}{l}\text { Sector of activity } \\
\text { Number of part- } \\
\text { ners }\end{array}$ \\
& 3 & $\begin{array}{l}\text { Year of training } \\
\text { completion }\end{array}$ \\
& & \\
& & \\
& $\begin{array}{l}\text { Identification of stra- } \\
\text { tegic criteria used by } \\
\text { inter-organizational } \\
\text { networks in partner } \\
\text { selection. }\end{array}$ & $\begin{array}{l}\text { 13 strategic crite- } \\
\text { ria that may or } \\
\text { may not be being } \\
\text { used in inter- }\end{array}$ \\
& & $\begin{array}{l}\text {-organizational } \\
\text { networks of the } \\
\text { sample }\end{array}$
\end{tabular}

II Criteria for selection of partners

Geringer (1991); Walters, Peters and Dess (1994); Doz (1996); Dacin, Hitt and Levitas (1997); Das and Teng (1998); Doumaet al. (2000); Spekman, Isabella and Macavoy (2000); Chung, Singh and Lee (2000); De Man, Duysters and Vasudevan (2001); Hagedoorn and Duysters (2002); Das and Teng (2002); Varis and Conn (2002); Poppo and Zenger (2002); Hagedoorn and Duysters (2002); Wahyuni (2003); Holtbrugge (2004); Vlaar, Van Den Bosch and Volberda (2006); Duisters, Duysters and De Man. (2011)

Kogut (1988); Devlin and Bleakly (1988); Contractor and Lorange (1988); Geringer (1991); Bronder and Pritzl (1992); Stafford (1994); Walters, Peters and Dess (1994); Brouthers, Brouthers and Wilkinson (1995); Doz (1996); Dacin, Hitt and Levitas (1997); Duysters et al. (1999); Das and Teng (1998); Tracey, Vanderembse and Lim (1999); Spekman, Isabella and Macavoy (2000); Douman (2000); Chung, Singh and Lee (2000); Perks (2000); De Man, Duysters and Vasudevan. (2001); Park and Ungson (2001); Spekman, Isabella and Macavoy (2000); Das and Teng (2002); Poppo and Zenger (2002); Nielsen (2003); Wahyuni (2003); Vlaar, Van Den Bosch and Volberda (2006); Dacin, Oliver and Roy (2007); Duisters, Duysters and De Man. (2011)

Identification of criteria related to the resources that are important for the selection of partners in inter-organizational networks.
2 criteria related to tasks that may or may not be 15 considered important in inter-organizational networks of the sample
Contractor and Lorange (1988); Geringer (1991); Stafford (1994); Das and Teng (1998); Spekman, Isabella and Macavoy (2000); Nielsen (2003); Duisters, Duysters and De Man. (2011) 
The sample is composed by different sectors, of which the trade sector is the one that presents greater representativeness, with $42.06 \%$. Following, what stands out is the service sector, whose activity is performed by $32.54 \%$ of the sample. Then, $18.25 \%$ of the sample operate in industrial activities, and $7.14 \%$ in agro-industrial economic activities.

In relation to the size of inter-organizational networks, the sample is very heterogeneous. The network with fewer partners has currently 4 , and the one with the largest number of partners has 410 , leaving an average of 43.67 partners.

Given the profile of the sample, below we present the main results for the criteria for partner selection.

\subsection{CRITERIA FOR THE SELECTION OF NEW PARTNERS}

Respondents rated the importance of 20 criteria for the selection of partners, drawn from diversified literature. For these criteria, managers defined, on a scale from 0 to 5 , the relative importance, and the average of the responses is exposed in Figure 2, showing the average of each criterion, clustering them according to the criteria of subgroups.

In this topic, we highlight first the criteria considered as most important, according to the managers: commitment was the criterion with the highest mean (4.73), which demonstrates a concern of managers of inter-organizational networks with respect to the commitment of the partners in the pursuit of common goals. This overview is positive, and the authors Doumaet al. (2000) and Varis and Conn (2002) consider the commitment between the partners as important success factors in inter-organizational relationships. Complementarily, the second featured criterion is the motivation to cooperate (4.62), which highlights the concern of managers of having partners in the network who are willing to cooperate, of living the assumptions of an inter-organizational network. This motivation implies a partner willing to contribute in joint tasks and in what regards more strategic issues.

Although no criterion received for its mean a value lower than " 3 ", we highlight that the three lowest means came from criteria related to the prospected. The mean 3.05 which is for size of the company enables us to understand that the sample considers indifferently the fact that the partners companies have a similar profile in terms of, for example, the number of employees. This indifference pointed to the criterion size of the company confronts the claim that cooperation work best when there is little difference in size between the companies (KOGUT, 1988; BROUTHERS, BROUTHERS and WILKINSON, 1995; and DUISTERS, DUYSTERS and DE MAN, 2011). The 3.15 mean for previous experience with cooperation stresses that managers are indifferent to the fact that prospected companies having previously participated in other collaborations. For the authors Devlin and Bleakly (1988); Dacin, Hitt and Levitas (1997); Chen, Lee and Wu (2008); Duisters, Duysters and De

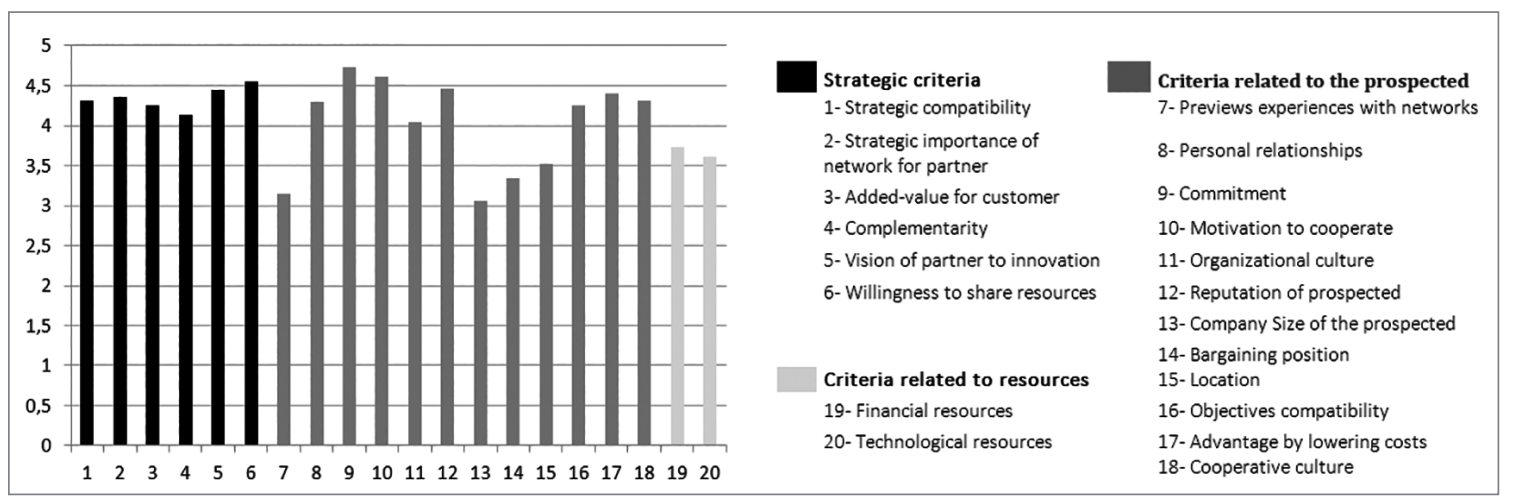

Figure 2: Average for the importance given to different criteria for the selection of partners Source: research data 
Table 3. Average importance and Cronbach's alpha for the three groups of criteria

\begin{tabular}{lcc}
\hline Criteria & Average importance & Cronbach's alpha \\
\hline Strategic criteria & 3.675 & 0.71 \\
Criteria related to the prospected & 4.340 & 0.836 \\
Criteria related to resources & 4.017 & 0.783
\end{tabular}

Source: research data

Man (2011), having previous experience with cooperation also assumes that the prospected has knowledge related to networks and a level of experience with network management with regard to the negative aspect of this criterion, the managers E2, E7, E8, E11 and E13 cited the fact that the companies that have already participated in networks, at first, left because they did have a good experience and that in this case, they enter the network with preconceptions and suspicions, as well as different notions of the cooperation process. The E2 respondent stated that "we prefer that our partners have never had previous experience in networks. Only this way, will they come without the bad habits form other networks". Respondent E11, stated that "it is better when the partner comes into the network for the first time, because only then they will see our way of working and will not compare with previous experiences that may not have been good for them."

In addition to these, the two criteria related to resources had a mean lower than 4: the importance given to the analysis of financial resources had a mean of 3.73 , and the importance of technological resources, 3.62. As a justification for these values, during the interviews the managers said that, depending on the sector, not many technological resources are indispensable and that the companies must have sufficient financial conditions to cope with their commitments, with a more detailed analysis of the financial resources available not being important. In another context, however, Duisters, Duysters and De Man (2011) found that the financial resources are important predictors for the performance of companies in the partnership. One explanation for this difference may lie in the manner of how the sharing of resources in each type of inter-organizational relationship occurs.

Also, in order to complement the emphasized aspects of each criterion, Figure 2 shows the information that the criteria related to the prospected are the most important ones to be evaluated when selecting new partners for business networks, with a mean of 4.34. In other words, more important than knowing the strategy and the resources of the prospected, is knowing what items concerning the manager's profile and the more operational issues related to the prospected company.

The criteria being analyzed in the prospected, as stated, were merged into three groups (strategic, related to the prospected and related to resources). For each group we calculated the mean of the importance given by managers, as well as the reliability of groups (Table 3 ).

It is worth noting that, according to Pasquali (2001), the internal consistency (Cronbach's alpha) consists in calculating the correlation that exists between each item of the test and the remaining items or the total (total score) of items to indicate a set (construct). In this sense, we present the following internal consistency of each set of criteria for the selection of new partners. As an acceptable reliability standard we adopted Cronbach's alpha values greater than or equal to 0.7 , as suggested by Hair et al., (2005).

Given the information in Table 3, concluded that the three sets of criteria (strategic, related to the prospected and related to resources) presented acceptable reliability, i.e., there is a correlation between the questions of each set, given the responses from respondent.

Respondents were also able to point out criteria that believe important for the analysis of the prospected, which had not been treated in the questionnaire. We highlight the criteria of trustworthiness, that was remembered by 8 respondents (E1, E2, E3, E6, E10, E12, E15 and E18). In relation to this criterion, the managers particularly stressed the importance of 
Table 4. Relation of criteria for the selection of partners

\begin{tabular}{|c|c|c|c|c|}
\hline $\begin{array}{l}\text { Criteria cate- } \\
\text { gory }\end{array}$ & Criteria & Definition & Authors & Sample comments \\
\hline \multirow{7}{*}{$\begin{array}{l}\text { Strategic } \\
\text { criteria }\end{array}$} & $\begin{array}{l}\text { Strategic compa- } \\
\text { tibility }\end{array}$ & $\begin{array}{l}\text { The partner's strategies } \\
\text { are compatible with the } \\
\text { Network's strategies; it } \\
\text { features the same policies } \\
\text { and tactics, which ensures } \\
\text { the alignment of objec- } \\
\text { tives. }\end{array}$ & $\begin{array}{l}\text { Williams and Lilley (1993); Dacin, Hitt } \\
\text { and Levitas (1997); Hagedoorn and } \\
\text { Duysters (2002); Das and Teng (2002); } \\
\text { Wahyuni (2003); Chen, Lee and Wu } \\
\text { (2008); Duisters, Duysters and De Man } \\
\text { (2011) }\end{array}$ & $\begin{array}{l}\text { Clarity of the company } \\
\text { and the network about } \\
\text { their plans }\end{array}$ \\
\hline & $\begin{array}{l}\text { Strategic im- } \\
\text { portance of the } \\
\text { network for the } \\
\text { partner }\end{array}$ & $\begin{array}{l}\text { How important the ne- } \\
\text { twork is for the partner }\end{array}$ & $\begin{array}{l}\text { Spekman, Isabella and Macavoy (2000); } \\
\text { Wahyuni (2003); Hagedoorn and } \\
\text { Duysters (2002); Das and Teng (2002); } \\
\text { Dacin, Hitt and Levitas (2007); Dekker } \\
\text { (2004); Poppo and Zenger (2002); Duis- } \\
\text { ter, Duysters and De Man (2011) }\end{array}$ & $\begin{array}{l}\text { The partner will only } \\
\text { continue as a partner if } \\
\text { there is the perception that } \\
\text { the network adds value to } \\
\text { their business. }\end{array}$ \\
\hline & $\begin{array}{l}\text { Added value for } \\
\text { the customer }\end{array}$ & $\begin{array}{l}\text { Undertaking in joint } \\
\text { activities add value to } \\
\text { customers }\end{array}$ & $\begin{array}{l}\text { Das and Teng (1998); Walters, Pe- } \\
\text { ters and Dess(1994); Doz (1996); De } \\
\text { Man, Duysters and Vasudevan (2001); } \\
\text { Wahyuni (2003); Duisters, Duysters and } \\
\text { De Man (2011) }\end{array}$ & $\begin{array}{l}\text { It is positive that the new } \\
\text { partner adds value to the } \\
\text { customer, when making } \\
\text { use of the brand's network. }\end{array}$ \\
\hline & Complementarity & $\begin{array}{l}\text { The partners are mutually } \\
\text { dependent to achieve their } \\
\text { goals }\end{array}$ & $\begin{array}{l}\text { Williams and Lilley (1993); Dacin, Hitt } \\
\text { and Levitas (1997); Spekman, Isabella } \\
\text { and Macavoy (2000); Hagedoorn and } \\
\text { Duysters (2002); Das and Teng (2002); } \\
\text { Doumaet al. (2000); Poppo and Zenger } \\
\text { (2002); Wahyuni (2003); Varis, Kuiva- } \\
\text { lainen and Saarenketo (2005); Vlaar et } \\
\text { al. (2006); Duisters, Duysters and De } \\
\text { Man (2011) }\end{array}$ & $\begin{array}{l}\text { Partners must have cha- } \\
\text { racteristics/resources tha } \\
\text { by being added enables } \\
\text { the achievement of com- } \\
\text { mon goals. }\end{array}$ \\
\hline & $\begin{array}{l}\text { Vision of the } \\
\text { partner for inno- } \\
\text { vation }\end{array}$ & $\begin{array}{l}\text { Willingness to innovate, } \\
\text { take risks, be creative }\end{array}$ & $\begin{array}{l}\text { Das and Teng (1998); Varis and Conn } \\
\text { (2002); Holtbrugge (2004); Dacin, Hitt } \\
\text { and Levitas (2007); Duisters, Duysters } \\
\text { and De Man (2011) }\end{array}$ & $\begin{array}{l}\text { Predisposition to change } \\
\text { procedures and practices } \\
\text { in order to achieve better } \\
\text { results. }\end{array}$ \\
\hline & $\begin{array}{l}\text { Willingness to } \\
\text { share resources }\end{array}$ & $\begin{array}{l}\text { Resources include em- } \\
\text { ployees, knowledge, } \\
\text { products, production } \\
\text { capacity }\end{array}$ & $\begin{array}{l}\text { Geringer (1991); Dacin, Hitt and Le- } \\
\text { vitas (1997); Chung, Singh and Lee } \\
\text { (2000); Duisters, Duysters and De Man } \\
\text { (2011) }\end{array}$ & $\begin{array}{l}\text { Resource sharing is essen- } \\
\text { tial to the growth of all the } \\
\text { members of the network. }\end{array}$ \\
\hline & $\begin{array}{l}\text { Previous ex- } \\
\text { periences with } \\
\text { cooperation }\end{array}$ & $\begin{array}{l}\text { Knowledge related to } \\
\text { networks, level of expe- } \\
\text { rience with network ma- } \\
\text { nagement }\end{array}$ & $\begin{array}{l}\text { Devlin and Bleakly (1988); Dacin, Hitt } \\
\text { and Levitas (1997); Chung, Singh and } \\
\text { Lee (2000); Marxt and Link (2002); } \\
\text { Chen, Lee and Wu (2008); Duisters, } \\
\text { Duysters and De Man (2011) }\end{array}$ & $\begin{array}{l}\text { The knowledge brought } \\
\text { from other corporations } \\
\text { contribute to the growth } \\
\text { of the network, but the } \\
\text { rules and procedures differ } \\
\text { and the new member must } \\
\text { adapt to the new pers- } \\
\text { pective. }\end{array}$ \\
\hline
\end{tabular}

Strategic compafeatures the same policies and tactics, which ensure the alignment of objec-

Strategic imortance of the ctivities add value to

\section{De Man (2011)}

Vision of the partner for innoWillingness to innovate, Personal relaEasy to live and relate to tionships the partner
Dacin, Hitt and Levitas (1997); Duysters et al. (1999); Dacin, Oliver and Roy (2007); Duisters, Duysters and De Man (2011)
Relationship favorable to conviviality in the network environment.
Criteria related to the prospected
Geringer (1991); Williams and Lilley (1993); Brouthers, Brouthers and Wilkinson (1995); Spekman, Isabella and Macavoy (2000); Douman (2000); De Man, Duysters and Vasudevan (2001); Marxt and Link (2002); Poppo and Zenger (2002); Nielsen (2003); Varis, Kuivalainen and Saarenketo (2005); Duisters, Duysters and De Man (2011) and Wilkinson (1995); Spekman et al.

Motivation to cooperate
Willingness to cooperate (2000); Douman (2000); De Man, Duysters and Vasudevan (2001); Nielsen (2003); Duisters, Duysters and De Man (2011)
Provision of time and dedication to the activities of the network 
BBR

14,3

331
Organizational

culture

Dacin, Hitt and Levitas (1997); Spek-

Reputation of the prospected

Company size of Number of employees, size the prospected of the physical structure

ditions organization, open or closed, etc.
Norms and values of the man, Isabella and Macavoy (2000);

Douma et al. (2000); Poppo and Zenger

(2002); Das and Teng (2002); Wahyuni

(2003); Vlaaret al. (2006); Chen, Lee and Wu (2008); Duisters, Duysters and De Man (2011)

Duysters et al. (1999); Dacin, Oliver

The image of the prospected

and Roy (2007); Duisters, Duysters an De Man (2011)

Kogut (1988); Williams and Lilley (1993); Brouthers, Brouthers and Wi-

lkinson (1995); Tracey, Vanderembse and Lim (1999); Duisters, Duysters and De Man (2011)

Walters, Peters an

(1996); Das and Teng (1998); Park e

Ungson (2001); De Man, Duysters and

Vasudevan (2001); Wahyuni (2003);

Duisters, Duysters and De Man (2011)

compared to other market

competitors

It does not interfere much in the progress of the network. It should only be the least in order to avoid conflicts that weaken the relationship and networking gains.

Level of credibility in the community and suppliers.

Minimum size to be able to develop their activities, according to the industry.

The better the bargaining condition is, the more favorable it is to the network.

Ensuring that the location is not an impediment to the company's participation in the activities and meetings of the network, and that it can undertake the logistics operations, if necessary.

\section{(2002)} and between company and customers
Geringer (1991); Marxt and Link

\begin{tabular}{|c|c|c|c|c|}
\hline \multirow{7}{*}{$\begin{array}{l}\text { Criteria related } \\
\text { to the pros- } \\
\text { pected }\end{array}$} & \multicolumn{4}{|r|}{ Optaturs, il mentssary. } \\
\hline & $\begin{array}{l}\text { Compatibility of } \\
\text { objectives }\end{array}$ & $\begin{array}{l}\text { The company has goals that } \\
\text { can be searched simultaneou- } \\
\text { sly with those of the other } \\
\text { members of the network, and } \\
\text { that they are complementary }\end{array}$ & $\begin{array}{l}\text { Bronder and Pritzl (1992); Brouthers, } \\
\text { Brouthers and Wilkinson (1995) }\end{array}$ & $\begin{array}{l}\text { The objectives sought in } \\
\text { the network must meet the } \\
\text { objectives of the prospected. }\end{array}$ \\
\hline & $\begin{array}{l}\text { Advantage by } \\
\text { reducing cost }\end{array}$ & $\begin{array}{l}\text { Economies of scale through } \\
\text { joint purchasing; reduction of } \\
\text { costs of each partner with the } \\
\text { accession of more partners } \\
\text { and consequent division of } \\
\text { transaction costs, improve- } \\
\text { ments, purchases with diffe- } \\
\text { rential prices }\end{array}$ & $\begin{array}{l}\text { Geringer (1991); Stafford (1994); Perks } \\
(2000)\end{array}$ & $\begin{array}{l}\text { Analysis of how the pros- } \\
\text { pected can contribute to the } \\
\text { reduction of shared costs or } \\
\text { better negotiations on joint } \\
\text { purchasing }\end{array}$ \\
\hline & $\begin{array}{l}\text { Cooperative } \\
\text { culture }\end{array}$ & $\begin{array}{l}\text { The new members are pre- } \\
\text { disposed to share knowledge }\end{array}$ & $\begin{array}{l}\text { Bronder and Pritzl (1992); Stafford } \\
\text { (1994); Brouthers, Brouthers and } \\
\text { Wilkinson (1995); Perks (2000) }\end{array}$ & $\begin{array}{l}\text { Cooperation reflected in the } \\
\text { trust to be established betwe- } \\
\text { en the partners. }\end{array}$ \\
\hline & Trustworthiness & $\begin{array}{l}\text { The new members (company } \\
\text { and entrepreneur) must } \\
\text { have a suitable behavior } \\
\text { and comply with their legal } \\
\text { obligations. }\end{array}$ & $\begin{array}{l}\text { Criteria that emerged from the data } \\
\text { collection. }\end{array}$ & $\begin{array}{l}\text { Appropriate behavior to the } \\
\text { community and suppliers. }\end{array}$ \\
\hline & $\begin{array}{l}\text { Analysis of clea- } \\
\text { rance certificates } \\
\text { (INSS, Federal } \\
\text { Revenue, ICMS, } \\
\text { among others) }\end{array}$ & $\begin{array}{l}\text { Características pessoais do } \\
\text { gestor da empresa; perspecti- } \\
\text { vas para a empresa. }\end{array}$ & $\begin{array}{l}\text { Critério que emergiu da coleta de } \\
\text { dados. }\end{array}$ & $\begin{array}{l}\text { Experiência em gestão, visão } \\
\text { de futuro. }\end{array}$ \\
\hline & $\begin{array}{l}\text { Entrepreneur's } \\
\text { profile }\end{array}$ & $\begin{array}{l}\text { Personal characteristics of the } \\
\text { company manager; prospects } \\
\text { for the company. }\end{array}$ & $\begin{array}{l}\text { Criteria that emerged from the data } \\
\text { collection. }\end{array}$ & $\begin{array}{l}\text { Management experience, } \\
\text { vision of the future. }\end{array}$ \\
\hline \multirow[b]{2}{*}{$\begin{array}{l}\text { Criteria related } \\
\text { to resources }\end{array}$} & Company lifetime & $\begin{array}{l}\text { The company's operating } \\
\text { time in the field of activity }\end{array}$ & $\begin{array}{l}\text { Criteria that emerged from the data } \\
\text { collection. }\end{array}$ & $\begin{array}{l}\text { The longer the time is, the } \\
\text { better the evaluation. }\end{array}$ \\
\hline & $\begin{array}{l}\text { Technological } \\
\text { resources }\end{array}$ & $\begin{array}{l}\text { Availability of technological } \\
\text { resources, technological } \\
\text { complementarities }\end{array}$ & $\begin{array}{l}\text { Das and Teng (1998); Spekman, Isa- } \\
\text { bella and Macavoy (2000); Nielsen } \\
\text { (2003); Chen, Lee and Wu (2008); } \\
\text { Duisters, Duysters and De Man (2011) }\end{array}$ & $\begin{array}{l}\text { Sufficient technological } \\
\text { resources so that it can work } \\
\text { in the field of activity }\end{array}$ \\
\hline
\end{tabular}

Fonte: dados da pesquisa 
analyzing whether the prospected has no legal restrictions (INSS, Federal Revenue, ICMS, among others). Also, knowing if the company has a trustworthy behavior over time before the community and suppliers.

The criteria manager's profile was also cited as being important by five respondents (E3, E9, E13, E14 and E17). In this criterion, the managers consider the evaluation of experience in management of the company's owner. The analysis of these criteria contribute, according to the respondents, to anticipate the kind of participation that the new partner will have on the network with respect to the assiduousness, the involvement in the management and even the sustainability of the partnership. E9 states that "the network is formed from relationships and because of that it is of an interest to us, in knowing the manager's profile of the company. If we analyze how they handle the management of the company, then we can see how they will behave with the network."

In addition to these criteria, managers E1 and E14 also stress the importance of knowing how long the company has been in the line of business. According to E14, "the operating length of time demonstrates the company's ability to overcome difficulties and, the longer the time of operation, the more renowned the company is, which also strengthens the network image."

By considering then the data collection performed from the questionnaires and interviews, next, we present Table 4 with the criteria that the sample of inter-organizational networks considered important for the selection of partners, with the relative specifications.

\section{FINAL CONSIDERATIONS}

This study's main objective was to identify the most important criteria for the selection of partners in horizontal inter-organizational networks, also proposing to describe their influence on network activities.

The first part of the data collection was performed through a questionnaire, covering a sample of 120 inter-organizational networks. The sample is composed of networks that have, on average operated for 10 years and have 43.67 partners. Twenty were the criteria surveyed a priori, divided as follows: 6 strategic criteria, 12 criteria related to the prospected and 2 criteria related to the tasks. From these, the criteria related to the prospected were considered as the most important to be evaluated when selecting new members, with a mean of 4.34 .

Of the twenty surveyed criteria, it was clear that the commitment had the highest mean (4.73) and it is related to the commitment associated with the success of the partnership. It should be noted that all the criteria surveyed in the questionnaire were considered by the sample with a mean higher than 3.0, which leads to the realization that, even though it was taken from the literature related to different types of inter-organizational relationships, all apply to the reality of the horizontal inter-organizational networks.

Based on this identification, interviews were conducted with managers of 16 interorganizational networks, from where other three criteria emerged considered as important for the selection of partners: trustworthiness, entrepreneur's profile and company lifetime.

Also, the sample of respondents points out three aspects to be considered. 1: the criteria cannot be so restrictive to the point that no company is able to meet with them, leading the network to have such a number of partners that its continuity is not made possible (E2); 2: the criteria cannot be too extensive, facilitating the entry of various company profiles, creating groups with different interests in the same network, decreasing the chances of them staying, when they do not perceive in the network a way to achieve the intended goals. This precaution was appointed by E14, being directly related to the attempt of trying to reduce the turnover of partners; 3 : the criteria should be reviewed periodically in order to adapt to changes and demands of the market and the actual inter-organizational network. 
BBR

14,3

Considering the breadth and depth of the results from the application of quantitative and qualitative method, we can observe that the criteria identified and described could contribute to a better selection process of partners. In theoretical terms, the research contributes by bringing up a reality of networks with peculiarities that deserve specific studies.

However, the study presents some limitations. Researchers jointly study the horizontal inter-organizational networks of the sample, regardless of sector specificities, number of associates or any other criteria for characterization. Given that, the statements and proposals should be made relative to the individual context of each inter-organizational network.

With the evidence found, we suggest for future studies to investigate the relationship of each partners selection criterion with the success of the partnership.

\section{REFERENCES}

ATOUBA, Y.; SHUMATE, M. Interorganizational networking patterns among development organizations. Journal of Communication, v. 60, n. 2, p. 293-317, 2010.

BEAMISH, P. W.; BANKS, J. C. Equity joint ventures and the theory of the multinational enterprise. Journal of International Business Studies, v. 18, n. 2, p. 1-16, 1987.

BIERLY III, P. E.; GALLAGHER, S. Explaining alliance partner selection: Fit, trust and strategic expediency. Long Range Planning, v. 40, p. 134-153, 2007.

BRONDER, C; PRITZL, R. Developing strategic alliances: a conceptual framework for successful cooperation. European Management Journal,v. 10, n. 4, p. 412-422, 1992.

BROUTHERS, K.; BROUTHERS, L.; WILKINSON, T. Strategic alliances: choose your partners. Long Range Planning, v. 28, n. 3, p. 18-25, 1995.

BRYMAN, A. Integrating quantitative and qualitative research: how is it done? Qualitative Research, v. 6, n. 1, p. 97-113, 2006.

CHEN, S.; LEE, H.; WU, Y. Applying ANP approach to partner selection for strategic alliance.Management Decision, v. 46, n. 3, p. 449-465, 2008.

CHILD, J.; FAULCKNER, D. Strategies of co-operation - managing alliances, networks, and joint ventures. New York: Oxford University Press, 1998.

CHUNG, S.; SINGH, H.; LEE, K. Complementarity, status similarity and social capital as drivers of alliance formation. Strategic Management Journal, v. 21, n. 1, p. 1-22, 2000.

CONTRACTOR, F. J.; LORANGE, P. Competition vs. cooperation: a benefit/cost framework for choosing between fully-owned investments and cooperative relationships. Management International Review, v.28, n. 4, P. 5-18, 1988.

DACIN, M. T.; HITT, M. A.; LEVITAS, E. Selection partners for successful international alliance, examination of U.S. and Korean firms. Journal of World Business, v. 32, n. 1, p. 3-16, 1997.

DACIN, M. T.; OLIVER, C.; ROY, J.-P. The legitimacy of strategic alliances: An institutional perspective. Strategic Management Journal, v. 28, n. 2, p. 169-187, 2007.

DAS, T. K. TENG, B-S.Between Trust and Control: Developing Confidence in Partner Cooperation in Alliances. The Academy of Management Review, v. 23, n. 3.p. 491-512, 1998.

DAS, T. K., TENG, B-S.A Resource-based Theory of Strategic Alliances. Journal of Management, V. 26, P. 31-61, 2000.

DAS, T. K.; TENG, B-S.The dynamics of alliance conditions in the alliance development process. Journal of Management Studies, v. 39, p. 725-746, 2002.

DEKKER, H. C. Control of inter-organizational relationships: evidence on appropriation concerns and cooperation requirements. Accounting, Organizations and Society, v. 29, n. 1, p. 27-49, 2004.

DE MAN, A. P.; DUYSTERS, G. M.; VASUDEVAN, A. The allianced enterprise: global strategies for corporate collaboration. London: Imperial College Press, 2001.

DEVLIN, G.; BLEAKLY, M. Strategic alliance: guidelines for success. Long Range Planning, v. 21, n. 5, P. 18-23, 1988.

DOUMA, M.; BILDERBEEK, J.; IDENBURG, P.; LOOISE, J. Strategic alliances: Managing the dynamics of fit. Long Range Planning, v. 33, p. 579-598, 2000.

DOZ, Y. L. The evolution of cooperation in strategic alliances: Initial conditions or learning processes?. Strategic Management Journal, v. 17, p. 55-83, 1996.

DUISTERS, D.; DUYSTERS, G.; DE MAN, A-P. The partner selection process: steps, effectiveness, governance. International Journal of Strategic Business Alliances, v. 2, n.1/2, p. 7-25, 2011. 
DYER, J. H.; CHU, W. The role of trustworthiness in reducing transaction costs and improving performance: Empirical evidence from the United States, Japan, and Korea. Organization Science, v.14, n.1, p.57-68, 2003.

EISENHARDT, K. M.; MARTIN, J. A. Dynamic capabilities: what are they? Strategic Management Journal, V. 21, p. 1105-1121, 2000 .

GAZLEY, B. Beyond the contract: The scope and nature of informal government nonprofit partnerships. Public Administration Review, v. 68, n. 1, p. 141-154, 2008.

GERINGER, J. M. Strategic determinants of partner selection criteria in international joint ventures. Journal of International Business, v. 22, n. 1, p. 41-62, 1991.

GULATI, R. Silo busting: transcending barriers to build high growth organizations. Harvard Business Review, v. 85, n. 5, p. 98-108, 2007.

GULATI, R; GARGIULO, M. Where do interorganizational networks come from? American Journal of Sociology, v. 104, n. 5, p. 1439-1493, 1999.

HAGEDOORN, J.; DUYSTERS, G. External appropriation of innovative capabilities: The choice between strategic partnering and mergers and acquisitions. Journal of Management Studies, v. 39, n. 2, p. 167-188, 2002.

HAIR JR., J. F.; BARRY, B.; MONEY, A. H.; SAMOUEL, P. Fundamentos de métodos de pesquisa em administração. Porto Alegre: Bookman, 2005.

HOLTBRUGGE, D. Management of international strategic business cooperation: Situational conditions, performance criteria, and success factors, Thunderbird International Business Review,v. 46, n. 3, p. 255 274, 2004.

INGRAM, P.; BAUM, J. A. C. Chain affiliation and the failure of Manhattan hotels, 1898-1980.Administrative Science Quarterly, v. 42, p. 68-102, 1997.

IRELAND, R. D.; HITT, M. A.; VAIDYANATH, D. Alliance management as a source of competitive advantage. Journal of Management, v. 28, n. 3, p. 413-446, 2002.

JARILLO, J. C. On strategic networks. Strategic Management Journal, v. 9, n. 1, p. 31-41, 1988.

KANTER, R. M. The art of alliances. Harvard Business Review, v. 72, n. 4, p. 96-108. 1994.

KEIL, T. Strategic Alliances - A review of the state of the art. Helsinki University of Technology, Intitute of Strategy and International Business. Working paper Series. 2000.

KEISTER. L. A. Engineering growth: Business group structure and firm performance in

China's transition economy. American Journal of Sociology. v. 104. P. 404-40, 1998.

KLEIN, L. L.; PEREIRA, B. A. D. Contribuições para a gestão de redes interorganizacionais: Fatores determinantes para a saída de empresas parceiras. Revista Eletrônica de Administração, v. 20, n. $2,2014$.

KOGUT, B. Joint ventures: theoreticalandempirical perspective. Strategic Management Journal, v. 9, n. 4, p. 319-332, 1988.

KUNZLER, M. T.; BULGACOV, S. As estratégias competitivas e colaborativas e os resultados individuais e coletivos no associativismo rural em Quatro Pontes (PR). Revista de AdministraçãoPública, v. 45, n. 5, p. 1363-1393, 2011.

LEE, S.; MONGE, P. The coevolution of multiplex communication networks in organizational communities. Journalof Communication, v. 61, n. 4, p. 758-779, 2011.

LIMA, P. E. da S. Redes interorganizacionais: uma análise das razões de saída das empresas parceiras. 2007. 104 f. Dissertação (Mestrado em Administração). Universidade Federal de Santa Maria, 2007.

MARXT, C.; LINK, P. Success factors for cooperative ventures in innovation and production systems. International Journal of Production Economics, v. 77, p. 219-229, 2002.

MÜLLER-SEITZ, G. Leadership in interorganizational networks: a literature review and suggestions for future research. International Journal of Management Reviews, v. 14, n. 4, p. 428-433, 2012.

NIELSEN, B. B. An empirical investigation of the drivers of international strategic alliance formation. European Management Journal, v. 21, n. 3, p. 301-322, 2003.

PARK, S. H.; UNGSON, G. R. Interfirm rivalry and managerial complexity: a conceptual framework of alliance failure. Organization Science, v. 12, n. 1, p. 37-53, 2001.

PERKS, H. Marketing information exchange mechanisms in collaborative new product development. Industrial Marketing Management, v. 29, n. 2, p. 179-189, 2000.

PFEFFER, J.; SALANCIK, G. R. The External Control of Organizations: A Resource Dependence Perspective, Harper \& Row, New York, 1978

POPPO, L.; ZENGER, T. R. Do formal contracts and relational governance act as substitutes or complements?. Strategic Management Journal, v. 23, n. 8, p. 707-725, 2002. 
BBR

14,3

PROVAN, K. G.; FISH, A.; SYDOW, J. Interorganizational networks at the network level: A review of the empirical literature on whole networks. Journal of Management, v. 33, n. 3, 2007.

QUATRIN, D. R. A expansão do número de associados em redes interorganizacionais como estratégia de crescimento: proposição de um modelo. 2015. 158 f. Dissertação (Mestrado em Administração), Programa de Pós Graduação em Administração, Universidade Federal de Santa Maria, Santa Maria.

SESAMPE. Programa Redes de cooperação. Estado do Governo do rio Grande do Sul, 2014. Disponível em: $<$ http://www.sesampe.rs.gov.br/redes_cooperacao.php\#mapa>. Acessoem: 10 set. 2014.

SPEKMAN, R. E.; ISABELLA, L. A.; MACAVOY, T.C. Alliance competence, maximizing the value of your partnerships. New York: John Wiley \& Sons, 2000.

STAFFORD, E. R. Using co-operation strategies to make alliance work. Long Range Planning, v. 27, n. 1, P. 6474, 1994.

TRACEY, M.; VANDEREMBSE, M. A., LIM, J. S. Manufacturing technology and strategy formulation: keys to enhancing competitiveness and improving performance. Journal of Operations Management, v. 17, n. 4, p. 411-28, 1999.

VARIS, J.; KUIVALAINEN, O.; SAARENKETO, S. Partner selection for international marketing and distribution in corporate new ventures. Journal of International Entrepreneurship, v. 3, p. 19-36, 2005.

VARIS, J.; SALMINEN, R. Selection of Potential Supplier Partners in a Turbulent Environment - A Theoretical Framework for the Partner Selection in the Infocom Market. In: 16th IMP-conference, Sep. 2000, Reino Unido, 2000. Disponível em: <http://www.impgroup.org/uploads/papers/132.pdf>. Acessoem: 19 aug. 2013.

VARIS, Y.; CONN, S. Alliance partner selection - a literature review. Telecom business research center Lappeenranta, Finland, 2002.

VLAAR, P.; VAN DEN BOSCH, F.; VOLBERDA, H. Coping with problems of understanding in interorganizational relationships: Using formalization as a means to make sense. Organization Studies, v. 27, n. 11, p. 1617-1638, 2006.

WAHYUNI, S. Strategic Alliance Development, a Study on Alliances Between Competing Firms. 2003. 295 f. Tese (Doutorado em Administração de Empresas)-Universidade Estatal de Groningen, Holanda, 2003. Disponível em: http://dissertations.ub.rug.nl/faculties/management/2003/s.wahyuni/. Acessoem: 15 jun. 2013.

WALTERS, B. A.; PETERS, S.; DESS, G. G. Strategic alliances and joint ventures: making them work. Business Horizons, Jul/Aug, p. 5-10, 1994.

WEGNER, D.; PADULA, A. D. Governance and management of horizontal business networks: an analysis of retail networks in Germany. International Journal of Business and Management, v. 5, n. 12, p. 74-88, 2010.

WILLIAMS, R. G.; LILLEY, M. M. Partner selection for joint-venture agreements. International Journal of project Management, v. 11, n. 4, p. 233-237, 1993.

WILSON, D. T. An Integrated Model of Buyer-Seller Relationships. Journal of the Academy of Marketing Science, v. 23, n. 4, p. 335-345, 1995.

WILLIAMSON, O. The economic of institutions of capitalism: firms, markets, relational contracting. New York: Free Pass, 1985. 